\title{
Research on the Relationship of Commercial Bank's Loan Loss Provision and Earning Management and Capital Management
}

\author{
Xianlei Dong ${ }^{1}$, Jia Liu' ${ }^{2}$, Beibei Hu ${ }^{1}$ \\ ${ }^{1}$ School of Economics and Management, Beijing University of Technology, Beijing, China; ${ }^{2}$ China Construction Bank of Shandong \\ Branch, Jinan, China. \\ Email: sddongxianlei@163.com
}

Received January $11^{\text {th }}, 2012$; revised February $24^{\text {th }}$, 2012; accepted March $5^{\text {th }}, 2012$

\begin{abstract}
This paper reviewed and analyzed the development of our nation's loan loss provision system, then studied the relations of commercial bank loan loss provision and earnings management and capital management through empirical study. This paper selected 14 domestic commercial banks of year 2001-2009 as data sample, using Kanagaretnam et al.'s (2003) research method, dividing the loan loss provision into two parts that is discretionary and nondiscretionary part, and empirically studied the relationship of discretionary part of loan loss provision and earnings before taxes and provisions (EBTP) and capital adequacy ratio (CAR). Empirical results show that: there is significant positive correlation between the discretionary loan loss provisions and earnings before taxes and provisions (EBTP), and there is significant negative correlation between the discretionary loan loss provisions and capital adequacy ratio (CAR). That provides evidence for the relation of bank loan loss provision and earnings management and capital management. In the last, combining with empirical research findings and the status of the loan loss provision system of China's commercial banks, this paper made several suggestions to improve the system of loan loss provision.
\end{abstract}

Keywords: Bank Loan Loss Provision; Earnings Management; Capital Adequacy Ratio

\section{Introduction}

Bank loan is one of the most important assets. The adequacy and accuracy of the extraction of bank loan loss provision not only affect the commercial bank's actual disclosure of financial condition and operating results, but also affect the risks related to the resilience of commercial banks, and consequently have an impact on the sound operation of banks. Therefore, the commercial banks should establish a scientific and rational system of loan loss provisions to address financial risks. The global financial crisis in 2008 had sounded the alarm, therefore we need to reexamine the reasonableness of our comercial bank loan loss provision system. Our nation's loan loss provision system was first established in 1988, then the relevant policies of loan loss provision is being in reform and improvement, but there still is a big gap between domestic practice and international practice.

As an asset impairment reserves, loan loss provision is a deduction item of accounting profits. The amount of its extraction not only influences the accounting profits, but also has certain maneuverability, while it is an estimate of the future loss that may occur. Therefore commercial bank loan loss provisions may affect the earnings management. The provision for loan losses is closely related to bank risks because general provisions can be included in supplementary capital, and specific provisions can be used as a deduction from risky assets. Therefore the loan loss provision is related to the regulatory capital adequacy ratio, which is probably related to capital management.

\section{Literature Review}

Some home scholars researches had been done on the LLP's influence to the surplus and capital management. Using surplus distributed model proposed by Burgstahler Dichev, Hu huanhuan and Lv guobing study on the surplus administrative behavior of our country's commercial banks, and find that both listed and unlisted commercial banks exist surplus management, they also find that listed commercial banks' surplus management are more serious than unlisted commercial banks' [1]. Xu youchuan and Yang jixian study on the motivation in LLP and surplus management of 42 commercial banks in our country, and believe that sample banks lack of man- 
agement motivation and demand [2]. Lv bo and Li changqiong study on the capital adequacy ratio's influence to the LLP counting and drawing of our country's comercial banks, and believe that banks have obviously procyclical effect, considering of tax avoidance, when yield is good, banks will add LLP counting and drawing in order to iron about income's rise and fall [3]. Li wen and $\mathrm{Xu}$ huanzhang study on the relationship between LLP and surplus management of 14 listed commercial banks, and believe that government should pay much more attentions to collecting and digesting data, and strengthen surveillance [4].

This paper hopes to acquire the relationship between LLP and surplus management by empirical analysis, and propose some suggestions on current condition in the surplus and capital management of our country's commercial banks.

\section{Methodology}

\subsection{Hypothesis}

Firstly, there maybe exists earnings management in Counting and Drawing of our country commercial bank's loan loss, it means, when current period profit is quite high, the management layer of bank will tend to count and draw more loan loss preparing, and prepare some reserve fund for future in order to cope with feasible profit fluctuating; when current period profit is quite low, the management layer of bank will tend to count and draw less loan loss preparing, and borrow reserve fund from future profit in order to smooth each year's profit. So, we make hypothesis:

Hypothesis 1: The loan loss preparing (LLP) is positive correlation with estimate before tax and loss preparing (EBTP).

Secondly, Counting and Drawing of commercial bank's loan loss has relation with banking capital managing, when banking capital adequacy ratio is quite high, the management layer of bank will count and draw less loan loss preparing; when banking capital adequacy ratio is quite low, the management layer of bank will replenish banking capital by counting and drawing more loan loss preparing in order to satisfy administering authority's demand. So, we make hypothesis:

Hypothesis 2: The loan loss preparing (LLP) is negative correlation with capital adequacy ratio (CAR).

\subsection{Models}

Step 1: Estimating DLLP. The LLP consists of two parts: not rulable LLP (NLLP) and rulable LLP (DLLP), which means:

$$
\text { LLP }=\text { NLLP + DLLP }
$$

First, NPL $\mathrm{t}_{\mathrm{t}-1}$ (front-bad-endfinance), CHNPL (bad loans for change), CHLOAN (total loans' variation) and WO (bad debt) are used through Kanagaretnam et al's research method [5] to estimate NLLP . Second, LLP subtracting NLLP gets DLLP. The more NPL $\mathrm{N}_{\mathrm{t}-1}$ is, the LLP is more, so NPL $\mathrm{t}_{t-1}$ is positive correlation with LLP. The more CHLOAN is, the more LLP is. So CHLOAN is positive correlation with LLP too. Using below formula to estimate NLLP:

$$
\begin{aligned}
\mathrm{LLP}_{\mathrm{it}}= & \alpha_{0}+\alpha_{1} \mathrm{NPL}_{\mathrm{it}-1}+\alpha_{2} \mathrm{CHNPL}_{\mathrm{it}} \\
& +\alpha_{3} \mathrm{CHLOAN}_{\mathrm{it}}+\alpha_{4} \mathrm{WO}_{\mathrm{it}}+\varepsilon_{\mathrm{it}}
\end{aligned}
$$

In which,

$\operatorname{LLP}_{\mathrm{it}-1}=$ loan loss preparation ratio;

$\mathrm{NPL}_{\mathrm{it}}=$ front-bad-endfinance/initial loan amount;

$\mathrm{CHNPL}_{\text {it }}=$ bad loans for change/initial loan amount;

CHLOAN $_{\mathrm{it}}=$ total loans' variation/front-bad-endfinance;

$\mathrm{WO}_{\text {it }}=$ bad debt/initial loan amount;

In Formula (2), the explanatory variables are used to estimate NLLP, and the DLLP is expressed in residual term.

Step 2: Adding EBTP (pre-tax and pre-loan loss preparation profit) and CAR (capital adequacy ratio) to the model through Ahmed et al.'s research method [6] for Empirical examining. This model includes four variables used to estimate NLLP and control variable's natural logarithm (LASSET). The DLLP becomes explained variable, the model formula is as follow:

$$
\begin{aligned}
\mathrm{LLP}_{\mathrm{it}}= & \beta_{0}+\beta_{1} \mathrm{NPL}_{\mathrm{it}-1}+\beta_{2} \mathrm{CHNPL}_{\mathrm{it}} \\
& +\beta_{3} \mathrm{CHLOAN}_{\mathrm{it}}+\beta_{4} \mathrm{WO}_{\mathrm{it}}+\beta_{5} \mathrm{LASSET} \\
& +\beta_{6} \mathrm{EBTP}_{\mathrm{it}}+\beta_{7} \mathrm{CAR}_{\mathrm{it}}+\varepsilon_{\mathrm{it}}
\end{aligned}
$$

In which,

$\mathrm{LLP}_{\mathrm{it}-1}=$ loan loss preparation ratio;

$\mathrm{NPL}_{\mathrm{it}}=$ front-bad-endfinance/initial loan amount;

$\mathrm{CHNPL}_{\text {it }}=$ bad loans for change/initial loan amount;

$\mathrm{CHLOAN}_{\mathrm{it}}=$ total loans' variation/front-bad-endfinance;

$\mathrm{WO}_{\text {it }}=$ bad debt/initial loan amount;

LASSET = the natural logarithm of bank's assets;

$\mathrm{EBTP}_{\text {it }}=$ the profit of pre-tax and pre-loan loss preparation/total assets;

$\mathrm{CAR}_{\text {it }}=$ capital adequacy ratio.

In the model, we expected that the pre-tax and preloan loss preparation profit (EBTP) and loan loss preparation (LLP) are positive correlation, while capital adequacy ratio (CAR) and loan loss preparation (LLP) are negative correlation. Besides, we also expect that the bad loans ratio (NPL) and loan loss preparation are significant positive-correlation, because there is more bad loans, more loan loss preparation should be prepared. 


\section{Results}

\subsection{Data Processing and Descriptive Statistical Analysis}

This paper selected a sample of China's 14 commercial banks dates from 2001 to 2009, data source from the Shenzhen State TYAN CSMAR Database. There were 18 commercial banks data in CSMAR database, but five banks of incomplete data, time cycle is short. Using these incomplete samples, the measurement result may lead to deviation. In order to improve the effectiveness of the empirical results, we remove five banks of incomplete data, which Guangdong Development Bank, Shanghai rural commercial bank, Chongqing commercial bank, the Bank of Beijing, Ningbo cooperative bank. The final selection of 14 banks, including the four major stateowned banks, Bank of China, China Construction Bank, Chinese agriculture bank, ICBC, and ten joint-stock commercial banks, industrial bank, Bank of communications, Shanghai Pudong Development Bank, Shenzhen Development Bank, Minsheng Bank, China Merchants Bank, CITIC Bank, China Everbright Bank, Hua Xia Bank and Bank of Shanghai.

This paper ultimately selected a sample of China's 14 commercial banks 9 years dates from 2001 to 2009, all data analysis using Eviews complete [7].

Our sample variables were descriptive statistics, the full sample, the state-owned banks, the joint-stock banks and during the economic crisis, respectively, as shown in table from one to three. Table $\mathbf{1}$ is the full sample, includes fourteen banks descriptive statistics of variables from 2001 to 2009, Table 2 is the descriptive statistics of four major state-owned banks and joint-stock banks, Table 3 is the descriptive statistics of economic crisis period and non-crisis period.

From contrast between the four major state-owned banks and joint-stock banks, we can find: the four major state-owned bank loan loss reserve rate is 0.007188 , the joint-stock bank loan loss reserve rate is 0.006211, the state-owned bank loan loss provision more fully; The state-owned banks bad loans rate is 0.118583 , joint-stock banks' bad loan rate is 0.043184 , so joint-stock banks for bad loans control more effectively than state-owned banks. The state-owned banks can be appropriate to consider learning joint-stock bank related management methods, appropriate to reduce bank bad loans, improve the bank economic benefits; The state-owned bank non-performing loan rate is -0.1219 , joint-stock banks non-performing loan rate is 0.009001 , illustrating that compared joint-stock banks, state-owned banks non-performing loans have significant decreasing trend in recent years; The state-owned banks profit margin is 0.010973 before loss preparation and pretax, joint-stock banks is 0.011026, illustrating that profit rate of joint-stock banks higher than the state-owned banks; The state-owned banks' capital adequacy ratio is 0.074517 , joint-stock banks' is 0.087818 , so joint-stock banks' capital adequacy ratio higher than state-owned banks'.

From contrast between the period of economic crisis and non-crisis, we can find: During the economic crisis, the average loan loss reserve rate is 0.007749 , and the average loan loss reserve rate of non-crisis is 0.006131 . During the economic crisis, the provision of more loan loss provision illustrates the loan loss provision has close cycle effect; The pre-tax and profit rate before loss preparation is 0.016417 in economic crisis period, and economic crisis period is 0.009466 , so the profit rate in economic crisis period higher than non-crisis period; The average capital adequacy ratio is 0.107343 during the economic crisis, but the average capital adequacy ratio is 0.077353 during the non-crisis. The economic crisis makes people confidence in the market decline, also led to banks and other enterprises in investment market conservative. Capital adequacy rate increased compared to non-crisis period, that loan loss reserve appropriately improve may be one reason.

\subsection{Empirical Results}

Based on the panel data, ordinary least squares (OLS)

Table 1. Full sample's descriptive statistics.

\begin{tabular}{|c|c|c|c|c|c|c|c|c|}
\hline Full Sample & LLP & NNPL & NPL & LOAN & WO & LASS & EBTP & CAR \\
\hline Mean & 0.00649 & -0.0284 & 0.064727 & 0.256087 & -0.001472 & -0.00276 & 0.011011 & 0.084018 \\
\hline Median & 0.006491 & -0.0284 & 0.03125 & 0.200415 & $-3.25 E-05$ & -0.16441 & 0.011318 & 0.09125 \\
\hline Maximum & 0.024751 & 0.880651 & 0.3066 & 1.080618 & 0.053025 & 2.466832 & 0.022576 & 0.1527 \\
\hline Minimum & -0.01343 & -0.84204 & 0 & -0.12981 & -0.090203 & -2.11921 & 0.000456 & -0.0147 \\
\hline Std. Dev. & 0.004893 & 0.235979 & 0.075737 & 0.188964 & 0.011511 & 1.259561 & 0.004897 & 0.040437 \\
\hline Observations & 126 & 126 & 126 & 126 & 126 & 126 & 126 & 126 \\
\hline Cross sections & 14 & 14 & 14 & 14 & 14 & 14 & 14 & 14 \\
\hline
\end{tabular}


Table 2. Descriptive statistics of four major state-owned banks and joint-stock banks.

\begin{tabular}{lccccccccc}
\hline Four Major State-owned Banks & LLP & NNPL & NPL & LOAN & WO & LASS & EBTP & CAR \\
\hline Mean & 0.007188 & -0.1219 & 0.118583 & 0.131942 & -0.00586 & 1.656405 & 0.010973 & 0.074517 \\
Median & 0.00803 & -0.06296 & 0.04655 & 0.117491 & -0.001835 & 1.668112 & 0.012469 & 0.0965 \\
Maximum & 0.01561 & 0.208928 & 0.3066 & 0.504054 & 0.007038 & 2.466832 & 0.022576 & 0.1405 \\
Minimum & 0 & -0.83845 & 0 & -0.12981 & -0.090203 & 0.927425 & 0.000456 & 0 \\
Std. Dev. & 0.004275 & 0.232129 & 0.107878 & 0.105348 & 0.016172 & 0.391116 & 0.006315 & 0.054705 \\
Observations & 36 & 36 & 36 & 36 & 36 & 36 & 36 & 36 \\
Cross sections & 4 & 4 & 4 & 4 & 4 & 4 & 4 & 4 \\
Joint-stock Banks & LLP & NNPL & NPL & LOAN & WO & LASS & EBTP & CAR \\
Mean & 0.006211 & 0.009001 & 0.043184 & 0.305745 & 0.000283 & -0.66642 & 0.011026 & 0.087818 \\
Median & 0.006438 & -0.02108 & 0.02495 & 0.256087 & 0 & -0.67807 & 0.011118 & 0.0908 \\
Maximum & 0.024751 & 0.880651 & 0.2358 & 1.080618 & 0.053025 & 1.196687 & 0.020371 & 0.1527 \\
Minimum & -0.01343 & -0.84204 & 0 & -0.05892 & -0.037651 & -2.11921 & 0.001564 & -0.0147 \\
Std. Dev. & 0.005114 & 0.228188 & 0.042862 & 0.192506 & 0.008506 & 0.780491 & 0.004243 & 0.032689 \\
Observations & 90 & 90 & 90 & 90 & 90 & 90 & 90 & 90 \\
Cross Sections & 10 & 10 & 10 & 10 & 10 & 10 & 10 & 10 \\
\hline & & & & & & & \\
\hline
\end{tabular}

Table 3. Descriptive statistics of economic crisis and non-crisis period.

\begin{tabular}{lcccccccccc}
\hline \multicolumn{1}{c}{ Non-crisis Period } & LLP & NNPL & NPL & LOAN & WO & LASS & EBTP & CAR \\
\hline Mean & 0.006131 & -0.00745 & 0.074907 & 0.277572 & -0.001323 & -0.13834 & 0.009466 & 0.077353 \\
Median & 0.006258 & -0.02607 & 0.04 & 0.221522 & 0 & -0.48644 & 0.010194 & 0.0863 \\
Maximum & 0.018482 & 0.880651 & 0.3066 & 1.080618 & 0.053025 & 2.466832 & 0.017061 & 0.1405 \\
Minimum & -0.00756 & -0.78509 & 0 & -0.12981 & -0.090203 & -2.11921 & 0.000456 & -0.0147 \\
Std. Dev. & 0.004545 & 0.226791 & 0.080197 & 0.205366 & 0.012383 & 1.278134 & 0.004122 & 0.040425 \\
Observations & 98 & 98 & 98 & 98 & 98 & 98 & 98 & 98 \\
Cross sections & 14 & 14 & 14 & 14 & 14 & 14 & 14 & 14 \\
Economic Crisis Period & LLP & NNPL & NPL & LOAN & WO & LASS & EBTP & CAR \\
Mean & 0.007749 & -0.10174 & 0.029096 & 0.180891 & -0.001995 & 0.471796 & 0.016417 & 0.107343 \\
Median & 0.008123 & -0.06198 & 0.0203 & 0.181644 & -0.001452 & 0.112529 & 0.016452 & 0.1127 \\
Maximum & 0.024751 & 0.230858 & 0.235 & 0.305506 & 0.010668 & 2.278052 & 0.022576 & 0.1527 \\
Minimum & -0.01343 & -0.84204 & 0.0068 & -0.12118 & -0.037651 & -1.17446 & 0.005382 & 0 \\
Std. Dev. & 0.005873 & 0.256617 & 0.041921 & 0.079077 & 0.007892 & 1.084276 & 0.003319 & 0.031205 \\
Observations & 28 & 28 & 28 & 28 & 28 & 28 & 28 & 28 \\
Cross Sections & 14 & 14 & 14 & 14 & 14 & 14 & 14 & 14 \\
\hline & & & & & & & \\
\hline
\end{tabular}

model, random effect model and fixed effect model are respectively constructed [8], and the results are as shown in Tables from 4 to $\mathbf{6}$. Form the results of the three methods, we find the degree of fitting of ordinary least squares regression and random effects regression are very low, unable to effectively forecast equation. Com- 
Table 4. Results of ordinary least squares (OLS) model.

\begin{tabular}{|c|c|c|c|c|}
\hline Variables & Numerical value & Standard error & T value & $P$ value \\
\hline C & 0.001963 & 0.002176 & 0.902084 & 0.3688 \\
\hline NNPL & 0.000249 & 0.002003 & 0.124348 & 0.9013 \\
\hline NPL & 0.011763 & 0.008177 & 1.438531 & 0.1529 \\
\hline LOAN & -0.0021 & 0.002848 & -0.73581 & 0.4633 \\
\hline Wo & -0.10569 & 0.0373 & -2.83361 & 0.0054 \\
\hline LASS & -0.00056 & 0.000422 & -1.31802 & 0.19 \\
\hline EBTP & 0.204286 & 0.138463 & 1.475383 & 0.1428 \\
\hline CAR & 0.022658 & 0.014966 & 1.513904 & 0.1327 \\
\hline \multicolumn{5}{|c|}{ Statistics result analysis } \\
\hline \multicolumn{2}{|c|}{$R^{2}$} & 0.14126 & $D W$ & 1.629382 \\
\hline \multicolumn{2}{|c|}{$\bar{R}^{2}$} & 0.090318 & $\mathrm{~F}$ & 2.77295 \\
\hline & & & $\mathrm{P}(\mathrm{F})$ & 0.00000 \\
\hline
\end{tabular}

Table 5. Results of random effect model.

\begin{tabular}{|c|c|c|c|c|}
\hline Variables & Numerical value & Standard error & T value & $P$ value \\
\hline C & 0.001963 & 0.002084 & 0.941677 & 0.3483 \\
\hline NNPL & 0.000249 & 0.001919 & 0.129805 & 0.8969 \\
\hline NPL & 0.011763 & 0.007834 & 1.501669 & 0.1359 \\
\hline LOAN & -0.0021 & 0.002729 & -0.7681 & 0.444 \\
\hline WO & -0.10569 & 0.035732 & -2.95798 & 0.0037 \\
\hline LASS & -0.00056 & 0.000405 & -1.37587 & 0.1715 \\
\hline EBTP & 0.204286 & 0.132642 & 1.540139 & 0.1262 \\
\hline CAR & 0.022658 & 0.014337 & 1.58035 & 0.1167 \\
\hline \multicolumn{5}{|c|}{ Statistics result analysis } \\
\hline \multicolumn{2}{|c|}{$R^{2}$} & 0.14126 & $D W$ & 1.629382 \\
\hline \multicolumn{2}{|c|}{$\bar{R}^{2}$} & 0.090318 & $\mathrm{~F}$ & 2.77295 \\
\hline & & & $\mathrm{P}(\mathrm{F})$ & 0.010512 \\
\hline
\end{tabular}

paring these three kinds of regression method, fixed effect model for the panel data regression results better, taking into account the section heteroscedasticity, thus used a section of weighted generalized least squares regression estimates, obtained ideal result.

From the regression results of table six, equation degree of fitting $R^{2}$ is 0.549 , indicate that the regression model goodness-of-fit is higher, explanatory variables have stronger explanatory capacity, and proceed with scientific forecast for dependent variables to a certain extent. At the same time, we notice that $P$ values of two variables NNPL and NPL are particularly high, and forecast they have multi co linearity. For this reason, we eliminate the variable NPL, use the fixed effects regression method, the results are as shown in Table 7.

After delete variable NPL, fitting $R^{2}$ become larger, while the other variables more significant $n$ the statistical, show linearity forecast is right. At the same time, $D W$ value is 1.735 , showing regression equation no correlation, and regression equation $\mathrm{F}$ statistic is $6.907, \mathrm{P}$ value is 0.000 , showing equation better fitting.

In the model, EBTP's coefficient is 0.462235 , whose $\mathrm{P}$ 
Table 6. Results of fixed effect model with GOLS of cross section weighting.

\begin{tabular}{|c|c|c|c|c|}
\hline Variables & Numerical value & Standard error & $\mathrm{T}$ value & $P$ value \\
\hline C & 0.003468 & 0.001897 & 1.827771 & 0.0704 \\
\hline NNPL & 0.0012 & 0.001534 & 0.78243 & 0.4357 \\
\hline NPL & 0.00051 & 0.00791 & 0.064502 & 0.9487 \\
\hline LOAN & 0.001458 & 0.001878 & 0.775934 & 0.4395 \\
\hline WO & -0.08275 & 0.041555 & -1.99127 & 0.049 \\
\hline LASS & -0.00143 & 0.000735 & -1.9452 & 0.0544 \\
\hline EBTP & 0.465819 & 0.129565 & 3.595253 & 0.0005 \\
\hline CAR & -0.031 & 0.014621 & -2.12037 & 0.0363 \\
\hline \multicolumn{5}{|c|}{ Constant coefficient deviation level of fixed effect } \\
\hline $004-C$ & 0.002908 & & $012-\mathrm{C}$ & 0.000342 \\
\hline $005-\mathrm{C}$ & 0.002294 & & $013-\mathrm{C}$ & -0.00179 \\
\hline $006-\mathrm{C}$ & 0.003694 & & $014-\mathrm{C}$ & -0.00129 \\
\hline $007-\mathrm{C}$ & 0.001885 & & $015-\mathrm{C}$ & -0.00157 \\
\hline $008-\mathrm{C}$ & -0.00145 & & $016-\mathrm{C}$ & -0.00748 \\
\hline $010-\mathrm{C}$ & 0.000632 & & $017-\mathrm{C}$ & 0.00053 \\
\hline $011-\mathrm{C}$ & -0.00093 & & $022-\mathrm{C}$ & 0.002212 \\
\hline \multicolumn{5}{|c|}{ Statistics result analysis } \\
\hline$R^{2}$ & 0.5493 & & & 1.736568 \\
\hline \multirow[t]{2}{*}{$\bar{R}^{2}$} & 0.463452 & & & 6.398546 \\
\hline & & & & 0.00000 \\
\hline
\end{tabular}

In which, 004 - 022 said of the 14 banks' code.

Table 7. Results of fixed effect model with GOLS of cross section weighting without NPL.

\begin{tabular}{|c|c|c|c|c|}
\hline Variables & Numerical value & Standard error & T value & $P$ value \\
\hline $\mathrm{C}$ & 0.003573 & 0.001292 & 2.765521 & 0.0067 \\
\hline NNPL & 0.00128 & 0.001507 & 0.849216 & 0.3977 \\
\hline LOAN & 0.001369 & 0.001829 & 0.748224 & 0.456 \\
\hline WO & -0.08355 & 0.041356 & -2.02032 & 0.0459 \\
\hline LASS & -0.00145 & 0.000721 & -2.01248 & 0.0467 \\
\hline EBTP & 0.462235 & 0.122636 & 3.76915 & 0.0003 \\
\hline CAR & -0.0311 & 0.01394 & -2.23087 & 0.0278 \\
\hline \multicolumn{5}{|c|}{ Constant coefficient deviation level of fixed effect } \\
\hline $004-\mathrm{C}$ & 0.002959 & & $012-\mathrm{C}$ & 0.000321 \\
\hline $005-\mathrm{C}$ & 0.002336 & & $013-\mathrm{C}$ & -0.00183 \\
\hline $006-\mathrm{C}$ & 0.003763 & & 014-C & -0.0013 \\
\hline 007-C & 0.001944 & & $015-\mathrm{C}$ & -0.00158 \\
\hline $008-\mathrm{C}$ & -0.00148 & & $016-\mathrm{C}$ & -0.00749 \\
\hline $010-\mathrm{C}$ & 0.000661 & & 017-C & 0.000483 \\
\hline $011-\mathrm{C}$ & -0.00095 & & $022-\mathrm{C}$ & 0.002163 \\
\hline \multicolumn{5}{|c|}{ Statistics result analysis } \\
\hline$R^{2}$ & 0.553192 & \multicolumn{2}{|c|}{$D W$} & 1.734578 \\
\hline \multirow[t]{2}{*}{$\bar{R}^{2}$} & 0.473104 & \multicolumn{2}{|c|}{$\mathrm{F}$} & 6.907287 \\
\hline & & \multicolumn{2}{|c|}{$\mathrm{P}(\mathrm{F})$} & 0.00000 \\
\hline
\end{tabular}

In which, 004 - 022 said of the 14 banks' code. 
value is 0.0003 , so the statistical result is significantly. It makes clear that LLP and EBTP are significant positivecorrelation, if EBTP changes a unit, then LLP would change 0.462235 units correspondingly in the same direction.

Regression coefficient value of CAR is 0.031 , whose $\mathrm{P}$ value is 0.0278 , so statistical result is significant. The result demonstrates that there is a significantly negative correlation between LLP and CAR, and CAR would change 0.031 units in the opposite direction if EBTP every change a unit.

Result of the positive correlation between LLP and EBTP verifies the hypothesis that the commercial banks of our country use the earnings management methods in loan loss preparation provisioning. When the banks' current profit is much higher, bank managers tend to plan more loan losses preparation for storing certain reserve in response to profit fluctuations' smooth in the future year. While the banks' current profit is lower, bank managers tend to plan less loan losses preparation, for smoothing profits of the current year by borrowing reserves from future earnings.

On the other hand, the result of negative correlation between LLP and CAR also verifies the hypothesis that the commercial banks of our country use the capital management methods in loan loss preparation provisioning. When the banks' capital adequacy ratio is higher, the bank managements tend to carry less loan losses preparation, while the banks' capital adequacy ratio is lower, the bank managements have more incentive to plan more loan losses preparation to add the bank capital in order to meet the regulatory requirements of the authorities.

According to the deviating level of constant term coefficient in fixed effect model's regression equation, the big four state-owned commercial banks' constant terms are positive deviation, meanwhile the other banks' constant terms are negative deviation. It indicates that the influence of selected independent variables is greater to big four state-owned commercial banks' LLP than to other banks'. Since the big four state-owned commercial banks are strong, and have the macropolicy supporting of the state, they are not sensitive to the influence of the external factors.

\section{Conclusions}

Combined with the change and development of Chinese Ready System for loan losses, two hypotheses are put forward by theoretical analysis. The Kanagaretnam, Lobo, Mathieu model is the reference of the empirical analysis. The empirical result supports the hypothesis, which shows that Chinese Ready System for loan losses is used for earnings management and capital management.
Chinese commercial banks manage the earning through manipulating the ready system for loan losses. The commercial banks adjust the annual accounting data, which is profit smooth by manipulating the ready system for loan losses. On the one hand, profit smooth can assure stable stock price and stable annual profit before tax, and enforce the invester's confidence. When the surplus of the banks in the current period is better, the managers of the banks could plan to extract more loan losses to prevent earnings to decrease in the future; when the surplus of the banks in the current period is worse, the managers of the banks could plan to extract less loan losses to improve current income to prevent big income fluctuations. On the other hand, avoiding tax is considered by profit smooth. When the own income of the commercial banks is better, increasing reserve fund can make the income fluctuations smooth.

Chinese commercial banks implement capital management by manipulating the ready system for loan losses. Based on the requirements of the capital adequacy ratio of supervision department, the banks managers hope to extract little loan losses when the capital adequacy ratio is high, and extract better loan losses when the capital adequacy ratio is low.

Chinese loan presents arbitrariness and can be handled during extracting, which is influenced by surplus management and capital management. From systems, the reason is the imperfect ready system for loan losses in China and the questions during extracting reserve fund. The information asymmetry between the borrower and the lender leads that it is not accurate to extracting the loan losses. Because five classification category loan method is not clear and the experience of managers is not enough, extracting loan losses is manipulated by some people.

\section{Suggestions}

The LLP has already become the tool to smooth profit and manage capital for operators in our country's commercial bank. Since our country's LLP system is not perfect, the LLP is always manipulated to smooth profit and manage capital for management layer of commercial bank. At present, our country's LLP system has many problems and defects, in order to perfect the bank's LLP system, some suggestions could be used to build up all-sided LLP management system which is compatible with internationally accepted practices, actual capital quality condition and our country's credit environment, they are:

1) Commercial bank ought to strengthen Pyatyi sort management;

Now according to the requirements of supervision department, Chinese commercial banks made the special 
criterions of five classification categories about loan quality and the inner management method to carry out five classification categories. But because the quantitative criterions in the guiding principle of the loan risk classification is less, and qualitative analysis depends on the knowledge, experience and skills of the classification persons, which could be subjective and optional, it is existed that person underestimates risk degree, such as that lost level loan is belonged to suspicious level, even junior level, or the suspicious level loan is belonged to junior level even attented level. However external risk rating is more strict and more really reflect risk attribute of the credit assest than inner risk rating. So the inner credit rating level will be improved through referencing reasonable and effective rating methods and techniques of the internal professional institute or entrusting a specialized rating agencies to implement the loan risk classification management.

On promoting a provision system reform, China Banking Regulatory Commission should require the commercial banks to improve the management strength on promoting the loan method, and improve continuously the accuracy of the five-classification category method on loan, and extract enough provision and do real profits to make capital adequacy ratio conforming to the standards. The commercial banks should also pay attention to capital adequacy ratio and the accuracy on extracting loan losses, and prevent manipulation behavior.

2) Commercial bank ought to build up foresight LLP system;

The LLP counting and drawing is not based on loss's beforehand prevention, but is based on NPLL(bad endfinance loss), so the LLP counting and drawing is always fall behind losing. The hysteresis quality of LLP counting and drawing not only causes hidden loss and overrating the profit and capital level of bank, but also causes CAR's cyclicality and encourage the cyclical swings of credit and economy. Just because of LLP system's hysteresis quality, china commercial banks ought to build up foresight LLP system which is not based on actual loss but is based on potential loan loss. At present, main methods of international banking's foresight LLP counting and drawing are "Expected cash flow of the discount methods", "Dynamic reserve method" and "Pressure test reserve method". From the angle of regulatory authority and bank, foresight LLP counting and drawing could keep operating steadily, reflect earning performance objectively, fit bank's steady operation principle and is benefic to financial system's stability.

3) Commercial bank ought to strengthen the LLP counting and drawing information disclosure.

Now for extracting provision the commercial banks depend on some subjective judgment to a great extent. It is not effective to supervise the commercial banks only by the supervision department. And now there are certain fuzzy more or less when Chinese commercial banks reveal the situation on the extracting provision for loan losses in annual report, and specially there is only a simple description on checking regularly the carrying value of all asset when they reveal the provision method. If there is objective evidence to indicate that the asset impairment occurred, the provision for impairment of assets is extracted. However, it is not detailedly disclosed on how the recyclable amount of the assets is forecasted and what is the forecasted result. The provision amount for impairment is obtained directly. At the same time it is not revealed that how impairment test is made and what is test result of single-major-sum financial assets because policy requests.

The accounting information users of the commercial bank need to achieve the real provision situation of the commercial bank from the public information of the commercial bank. If the public information is not uniformed or not perfect, the information users would have trouble in understanding the commercial bank management situation. But the effective public information could force the commercial bank to improve the provision level under market pressure. So these two reasons also require to improve the commercial banks information-disclosed system to assure the provision system for loan losses to be implemented fully.

In view of this situation, the commercial banks should improve the information-disclosed to avoid that the commercial banks undertake profit manipulation and capital management by manipulating the provision for loan losses and faintly disclosing the information. The suggestions from three respects are provided in this paper to assure the disclosing-information system of the comercial banks is perfect and effective. Firstly, the uniform format and content of disclosed information should be laid down, and the specific objective evidence on various assets impairment and the recyclable amount situation it should be shown clearly. Secondly, the punishment policy to violate the system should be established. The system implementing should be forced, and the policy is made to punish the top management who violates the disclosing-information system and assure the responsibility for disclosing information. The bank chief managers who don't perform or slack the responsibility for disclosing information and hide the important information and deliberately give the inaccurate information should be punished severely. The punishing measures include affixing the responsibility of the related responsible persons and giving certain financial penalties when the thing is serious. Thirdly, the supervisory authority should explicit the frequency of the commercial banks disclosing infor- 
mation according to the relevant require to extract the provision, and assure to master timely the provision level of the commercial banks.

\section{REFERENCES}

[1] H. H. Hu and G. B. Lv, "Research on Earnings Management of China Commercial Banks upon Surplus Distributed Model,” Economic Management, Vol. 6, 2010, p. 32.

[2] Y. C. Xu and J. X. Yang, "Research on Earnings Management Motivation and LLP of Commercial Banks," Economic Science, Vol. 2, 2010, pp. 94-103.

[3] B. Lu and C. Q. Li, "Research on the Capital Adequacy Ratio's Influence to the LLP Counting and Drawing of China Commercial Banks-Investigation of Procyclical Effect and Ironing Income Effect," Wuhan Finance, Vol. 6, 2009, pp. 56-58

[4] W. Li and H. Z. Xu, "Empirical Analysis on the Relationship between LLP and Surplus Management of Listed
Commercial Banks,” Finance and Accounting Monthly, Vol. 5, 2011, pp. 14-15.

[5] K. Kanagaretnam, G. Lobo and R. Mathieu, "Managerial Incentives for Income Smoothing through Loan Loss Provisions," Review of Quantitative Finance and Accounting, Vol. 20, No. 1, 2003, pp. 63-80. doi:10.1023/A:1022187622780

[6] A. Ahmed, C. Takeda and S. Thomas, "Bank Loan Loss Provision: A Reexamination of Capital Management, Earnings Management and Signaling Effects," Journal of Accounting and Economics, Vol. 28, No. 1, 1999, pp. 125. doi:10.1016/S0165-4101(99)00017-8

[7] H. H. Fan and L. Y. Zhang, "Eviews Statistics Analysis and Use,” China Machine Press, Beijing, 2009.

[8] J. Wooldridgy, "Econometric Analysis of Cross Section and Panel Data," China Renmin University Press, Beijing, 2007. doi:10.1016/S0165-4101(99)00017-8 